\title{
$\mathbf{I}$
}

\section{Dissymmetry Embodied: Feminism, Universalism, and the Practice of Excision}

\author{
FRANÇOISE LIONNET
}

\begin{abstract}
What is most needed is some kind of special illumination of the structural dissymmetry that runs all through and conditions the entire fabric of social and individual life.
\end{abstract}

-Fatima Mernissi

The experience of academic feminist criticism since the 1970 s has created almost insurmountable differences between "Western" modes of analysis of the concrete status of women in various non-Western cultures on the one hand, and non-Western women's subjective experience of their own position on the other. Whether it is conflict between "American" and "French" approaches, "essentialist" and "poststructuralist" epistemologies, or "first" and "third" world women, differences of ideology fuel disagreements that threaten to preclude dialogue. In such a climate it has become imperative to reexamine the ground from which such conflicts develop, and to try to modulate and nuance the conceptual frameworks that generate these oppositions. To do so, I would like to propose a truly comparative feminist criticism, one that is performed on the border between those disciplinary categories. Such an approach aims not at conflict resolution but rather at reframing the issues in such a way that dialogue can remain open and productive, allowing critics to map out new articulations of cultural expressions.

Some critics have suggested that feminism should not be considered a "unitary entity ... in which conflicts can or should be contained," and that feminist activism cannot be subsumed "under the illusion of a

I thank Nawal El Saadawi for her interest in this essay, the friends and colleagues who made generous and careful comments on an early draft, and the participants in the 1990 Harvard English Institute, where this essay was first read. A short version was published in Passages 1 (1991), and is reprinted by permission. I also thank the Rockefeller Foundation for supporting my work during 1991-92. All translations are mine, unless otherwise noted. My epigraph is from Fatima Mernissi, Beyond the Veil: Male-Female Dynamics in Modern Muslim Society (Bloomington: Indiana University Press, 1987), ix. 
unitary governing ideal," be it "woman" or "truth."1 This argument implies that we might be ill advised to appeal to a set of "universal" (i.e., Western humanist) values which would allow feminists to come to a consensus about the possibility of sharing certain beliefs or points of view regarding both the nature and function of feminism as a global process, and the social construction of femininity within different cultural contexts. The point is well taken: ethnocentric value judgments have no place within a truly diverse, multicultural, and multiracial feminist inquiry.

Yet there is a distinction to be made between cultural and moral relativism. The question of universalism comes back to haunt us if we do not carefully examine the consequences of a cultural relativism marked by ignorance of, and indifference to, everything non-Western, and thus exemplifying what Kathleen Barry has called a form of "Western liberal particularism that says 'hands off' to anything produced in ThirdWorld nations or cultures." Antiethnocentrism can have the unfortunate consequence of undermining feminist political solidarity, and this kind of liberalism reinforces "Third World masculinist nationalism [which] ... attempts to isolate women in their cultures and identify western women as their enemy." ${ }^{2}$ It is therefore important to continue speaking of community, and to attempt to find a common theoretical and ethical ground from which to argue for political solidarity without either objectifying the "other" woman or subsuming collective goals under the banner of sameness. As Gayatri Spivak stated more than a decade ago: "However unfeasible and inefficient it may sound, I see no way to avoid insisting that there is a simultaneous other focus: not merely who am I? but who is the other woman? How am I naming her? How does she name me?"'3

I enter the debates on universalism and particularism by briefly ex-

'Marianne Hirsch and Evelyn Fox Keller, eds., Conflicts in Feminism (New York: Routledge, Chapman \& Hall, 1990), 2.

${ }^{2}$ Kathleen Barry, foreword to Evelyne Accad, Sexuality and War: Literary Masks of the Middle East (New York: New York University Press, 1990), ix. I am emphatically suggesting not that Hirsch and Keller are guilty of this kind of liberalism but that their theoretical positions might lead to such logical consequences.

"Gayatri Spivak, "French Feminism in an International Frame," Yale French Studies 62 (1981): 179. These lines have been cited by numerous feminist critics who have used it to underscore the need for a "particularist" or "relativist" approach to the study of different cultures. See Elizabeth Abel, "Race, Class, Psychoanalysis? Opening Questions," in Hirsch and Keller, Conflicts in Feminism, 197-99; Jane Gallop, "The Monster in the Mirror: The Feminist Critic's Psychoanalysis," in Feminism and Psychoanalysis, ed. Richard Feldstein and Judith Roof (Ithaca: Cornell University Press, 1989), 13-24; and Helena Michie, "Not One of the Family: The Repression of the Other Woman in Feminist Theory," in Discontented Discourses: Feminism/Textual Intervention/Psychoanalysis, ed. Marleen S. Barr and Richard Feldstein (Urbana: University of Illinois Press, 1989), 15-28. 
amining the discursive contexts of a concrete and specific ritual practice: the phenomenon of female excision and infibulation, which is performed in parts of Africa and the Middle East, and which constitutes an important aspect of the cultural identity of Islamic women. ${ }^{4}$ These ritual practices, often defined as various forms of sexual mutilation, have since colonial times been denounced by missionaries, colonial administrators, Western media, feminist critics, and health service professionals. They have decried the existence of such "ethnic" customs as "barbaric" or "anachronistic," that is, in terms that often smack of racist, anti-Islamic rhetoric. In the 1970s-especially after 1975, which was declared International Women's Year by the United Nations-the issue suddenly mobilized European and American feminists, to the point that in 1979, Renée Saurel could claim that those practices "have caused much blood to be shed for thousands of years, and much ink for the past two."

In contemporary Western medical and anthropological literature, and in journalistic reports, the subject of excision is often treated peremptorily, in an impassioned, reductionist, and/or ethnocentric mode which represents the peoples who practice it as backward, misogynistic, and generally lacking in humane and compassionate inclinations: in other words, as has always been the case with respect to Africa and Africans, the dominant rhetoric emphasizes lack, absence, failure, inhumanity, and greed. ${ }^{6}$ Unfortunately, counterarguments also tend to use inflammatory language. In an interview Mamadou Kante links the recent interest shown by Europeans in the sexual lives of African women to their desire to control the birthrate in Africa: "Everyone knows that if they [i.e., the Western powers] succeed in controlling women under one pretext or another, then the birth-rate in Africa will be under control. Under the misleading pretext of excision, that is the hidden agenda. Such is the realm of occult political forces. ${ }^{\prime 7}$

${ }^{4}$ There are three main types of female circumcision. Clitoridectomy, considered to be the equivalent of male circumcision, consists in the removal of the prepuce of the clitoris. Excision is the removal of the prepuce, the clitoris itself, and the labia minora. Infibulation consists in the removal of the clitoris, "the whole of labiae minora and majora, and the stitching together (suturing) of the two sides of the vulva leaving a very small orifice to permit the flow of urine and menstrual discharge." See Olayinka Koso-Thomas, The Circumcision of Women: A Strategy for Eradication (London: Zed Books, 1987), 16-17.

${ }^{5}$ Renée Saurel, L'enterrée vive (Geneva: Slatkine, 1981), 20.

"Anne de Villeneuve, "Étude sur une coutume somali: les femmes cousues," Journal de la société des africanistes 7. 1 (1937): 15-32; Fran Hosken, The Hosken Report: Genital and Sexual Mutilation of Females (Lexington, Mass.: Women's International Network News, 1982), 201; and Françoise Lionnet, "Identity, Sexuality, Criminality: 'Universal Rights' and the Debate around the Practice of Female Excision in France," Contemporary French Civilization 16 (Summer 1992): 294-307.

${ }^{7}$ Mamadou Kante, "L'excision," Présence africaine 142 (1987): 180. 
Kante may well be justified in questioning the Western powers' motives behind the campaign for birth control: the concern about "galloping demography" in nonwhite countries is indeed laced with racist fears and instincts for self-preservation stemming from the fact that whites are a global minority, and a wealthy one, intent on curbing growth among those generally poorer than they are. But is it really fair to link the fight against excision to the racist wish to control nonwhite women's reproductive capabilities? Or does this accusation simply blur the real issue, marginalizing the female victims while the two opposing sides trade abuse and insults? Statistics do show that excision and infibulation can have lethal side effects that contribute to increased mortality rates for mothers and infants at the moment of delivery. ${ }^{8}$ To thus conflate the Western fears about higher birthrates in the "third world" with the human rights issue of maternal and infant health seems to be a downright contradiction. But, of course, birth control information did make its entrance into Africa with the same health care professionals who have denounced genital mutilations in moralizing terms. The attitude of suspicion exemplified by Kante is easy to understand even if one cannot agree with it.

Unfortunately, the generally offensive rhetoric leaves little room for the careful examination of two competing claims: on the one hand, the campaign for the abolition of all such ritual practices on the basis of a universal ethical imperative against the physical torture and psychological impairment of millions of women; ${ }^{9}$ on the other hand, a claim of respect for the cultural autonomy of African societies critical of any feminist intervention as "acculturation" to Western standards.

Yet African women themselves have, in no uncertain terms, proclaimed that the issue is theirs to debate and discuss. Of several texts by African women who examine the problem with great care, three are particularly noteworthy: The Circumcision of Women: A Strategy for Eradication by Olayinka Koso-Thomas is a well researched document, focused on Sierra Leone, which outlines a twenty-year plan for eradication; La parole aux négresses by Awa Thiam is a compilation of interviews with women from francophone and anglophone West African states (Ivory Coast, Guinea, Mali, Senegal, Ghana, and Nigeria); and The Hidden Face of Eve by Nawal El Saadawi raises the issue as it

\footnotetext{
${ }^{8}$ See Michel Erlich, La femme blessée: essai sur les mutilations sexuelles féminines (Paris: L'Harmattan, 1986), 132-33; and Koso-Thomas, Circumcision of Women, 27.

${ }^{9}$ There are approximately 80 to 100 million excised women in the world today. Of those, about 5 million have also undergone infibulation. See Erlich, Femme blessée, 277, and Alice Walker, Possessing the Secret of Joy (New York: Harcourt Brace Jovanovich, 1992), 281 .
} 
relates to North Africa and the Middle East. Saadawi's novel Woman at Point Zero is, with Evelyne Accad's L'excisée, one of the few fictional accounts written with moving sincerity and autobiographical detail. It is a more effective and convincing denunciation than many pragmatic or political treatises because it allows the reader to enter into the subjective processes of the individual, to adopt her stance. ${ }^{10}$

These writers are all Western-trained feminist intellectuals or scientists (Koso-Thomas and Saadawi are physicians) who denounce the practice from the vantage point of the educated elite-hence, some have argued, from a perspective more "Western" than "African," and thus alienated from the masses, who would neither read them nor sympathize with their views. There is, in other words, a dissymmetry of class and ideology between them and the uneducated masses, a dissymmetry that is inevitable, since literacy and education remain, to a large extent, steps that favor Westernization. But there are important indications that "progress" is being made; arguments in favor of a form of cultural relativism that would excuse excision on strictly cultural grounds do not have as much currency as some vocal critics of interventionism might lead us to believe.

Indeed, a close examination of some defenses of excision tends to reveal inconsistencies. For example, although Joséphine Guidy Wandja argues in favor of the specificity of African sexuality, and stresses the deep meaning ("signification profonde") of traditional African rituals, declaring that "the African model of sexuality cannot be ... the same as the European model," she nonetheless must conclude her essay in defense of particularism with a "universally" valid statement that grounds sexuality in the materiality of the body. She does so despite her earlier emphasis on the "optique spiritualiste" of secular African traditions, which she had previously contrasted to the mechanistic and materialist approach of the Americans Masters and Johnson. She asks: "Indeed, how is it possible to explain the age-old customs of a people on the basis of very recent discoveries (2oth century)? One can read, for example, that excision suppresses women's right to experience pleasure, but in their research, specialists would have to give a unanimous definition of pleasure."11

${ }^{10}$ Koso-Thomas, The Circumcision of Women; Awa Thiam, La parole aux négresses (Paris: Denoël/Gonthier, 1978); Nawal El Saadawi, The Hidden Face of Eve: Women in the Arab World, trans. Sherif Hetata (London: Zed, 1980), and Woman at Point Zero, trans. Sherif Hetata (London: Zed, 1983); Evelyne Accad, L'excisée (Paris: L'Harmattan, 1982). Subsequent citations of Woman at Point Zero and The Hidden Face of Eve appear in the text.

${ }^{11}$ Joséphine Guidy Wandja, "Excision? mutilation sexuelle? mythe ou réalité?" Présence africaine 142 (1987): 58, 56. 
If the issue is one of defining what constitutes "pleasure," then it seems acceptable to relativize the definition according to sociocultural context and/or sexual preference. But Wandja never questions "le droit au plaisir," the right of women to be sensually and/or sexually fulfilled. As a matter of fact, she grounds the ethical problem in the physicality of the body, universalizing the well-being (if not the full integrity) of that body. Hence, one might argue, her position does not invalidate the search for an ethical imperative. Moreover, Wandja falls into what is perilously close to contradiction, for the other side of the coin remains the question of pain: How is it possible to reconcile the fundamental human right to pleasure with the willful infliction of pain on the body of the female child? ${ }^{12}$ Her particularist approach fails to justify relativism.

There are, however, in all cultures many practices that aim at regulating, transforming, and "improving" the body. I would be falling into the ethnocentric trap if I did not point out that in the West, the pursuit of an elusive ideal of femininity is also mediated by pain (inflicted by the corset, for example). French-speaking female children grow up hearing that "il faut souffrir pour être belle" (you must suffer to be beautiful), and the pain of childbirth has generally been considered the "normal" fulfillment of a woman's destiny-a rite of passage, a difficult but necessary ritual. Similarly, excision and circumcision are considered rites of passage, initiatory practices the purpose of which is precisely to test the mettle of the individual, her endurance of pain, her ability to remain impassive and stoic in the face of severe discomfort. It is a "character-building" experience. It creates solidarity, closeness, and sisterhood among the initiates. Thus, as Wandja puts it, a successful initiation confers respect and dignity on the child now become woman. As an initiatory practice, excision serves the same purpose as other forms of ritualized violence in many different cultures (e.g., fraternity hazing and its occasionally fatal consequences). Furthermore, excision is an operation that has an aesthetic function-on a par with plastic surgery and other (Western) forms of self-denial: what Susan Bordo has called the "normalizing disciplines of diet, make-up, and dress ... [through which] we are rendered more... focused on self-

\footnotetext{
${ }^{12} \mathrm{Need}$ I state that all published oral testimonies of educated and illiterate women dwell on the painful aspect of the procedure and its sequels, even if some interviewees maintain that their sexual response (i.e., their ability to experience orgasm) is not affected? See Chantal Patterson, "Les mutilations sexuelles féminines: l'excision en question," Présence africaine 142 (1987): "At this stage of the debate I would like to stress the following points: 1. Different civilizations live, practice, and conceptualize eroticism and sensuality differently. 2. If there is any mutilation, a system of compensation must be set in motion by the body, this extraordinary machine" (165).
} 
modification.... [These] practices of femininity may lead us to utter demoralization, debilitation, and death." ${ }^{\prime \prime 3}$

That is why, I would argue, it is quite possible to link excision to the general cultural paradigm of the reproduction of femininity and its concomitant depersonalizing effects. Marie Bonaparte, who had the opportunity to examine many excised women in Egypt in the 1930s, speculated, with Freud, that the practice stemmed from a wish to maximally "feminize the female" by removing the clitoris, "this cardinal vestige of her masculinity," and to intimidate and suppress the child's sexuality. But she also noted that "the physical intimidation of the girl's sexuality by this cruel excision would not achieve the aim of feminizing, vaginalizing her, any better than the psychical intimidation of the clitoridal masturbation of European little girls. ${ }^{\prime 14}$ Since the operation suppresses genital structures which are "phallic," the ethnopsychiatrist Michel Erlich adds, the psychological dimension of these operations are "inscribed as the specific manifestation of masculine castration anxiety in front of the "castrated" female sexual organ." In this reading of the practice, male fears of women's sexuality would be the unconscious motivation for exaggerating, and thus controlling, femininity. But, paradoxically, infibulation, which might first appear to be a "hyperfeminization" of the genitalia, can also on the contrary be interpreted as a "phallisation" of the vulva, which has been rendered smooth and convex, thus evoking "a phantasmatic phallus." These conflicting yet complementary interpretations underscore the arbitrariness with which a visually based, and apparently "objective," interpretive grid can be used. The ambiguities and indeterminacies stressed by Erlich point toward the "thickness" or polyvalent nature of all symbolic systems, as Clifford Geertz has shown..$^{15}$ It is clear that there are embedded incoherences in the signifying text of culture, and there can be no simple cause, and therefore no simple "solution," to the complex cultural phenomena known as practices of genital mutilation. As Tobe Levin declares: "Western activists must learn to enter the value system of the 'circumcised' to avoid the counter-productive approach based on ignorance and indignation alone." 16

${ }^{13}$ Wandja, "Excision?" 57. Susan R. Bordo, "The Body and the Reproduction of Femininity: A Feminist Appropriation of Foucault," in Gender/Body/Knowledge: Feminist Reconstructions of Being and Knowing, ed. Alison M. Jaggar and Susan R. Bordo (New Brunswick: Rutgers University Press, 1989), 14. See Erlich, Femme blessée, 183, for a comprehensive survey of the "aesthetic" argument.

${ }^{14}$ Marie Bonaparte, Female Sexuality, trans. John Rodker (New York: International Universities Press, 1953), 207.

${ }^{15}$ Ehrlich, Femme blessée, 14. Clifford Geertz, The Interpretation of Cultures (New York: Basic Books, 1973).

${ }^{16}$ Tobe Levin, “Women as Scapegoat of Culture and Cult: An Activist's View of Female 
It is by pointing out some of the incoherences in cultural practices that we can begin to make sense of them. Indeed, the "official" discourse-on both sides of the ideological fence separating abolitionists from traditionalists-tends to overemphasize coherence, in the one case by appealing to abstract humanitarian notions, in the other by claiming the importance of cultural autonomy and specificity. In 1985 the president of Senegal, Abdou Diouf, stated the position of his government:

Female mutilation is a subject that is taboo.... But let us not rush into the error of condemning [genital mutilations] as uncivilized and sanguinary practices. One must beware of describing what is merely an aspect of difference in culture as barbarous. In traditional Africa, sexual mutilations evolved out of $a$ coherent system, with its own values, beliefs, cultural and ritual conduct. They were a necessary ordeal in life because they completed the process incorporating the child in society.

These practices, however, raise a problem today because our societies are in a process of major transformation and are coming up against new socio-cultural dynamic forces in which such practices have no place or appear to be relics of the past. What is therefore needed are measures to quicken their demise. The main part of this struggle will be waged by education rather than by anathema and from the inside rather than from the outside. I hope that this struggle will make women free and "disalienated," personifying respect for the eminent dignity of life. ${ }^{17}$

President Diouf invokes a "coherent system" of traditions to which he opposes the "new socio-cultural dynamic forces in which [the old practices] have no place." In other words, two symmetrical and coherent systems seem to be opposed, the new displacing the old, the need to disalienate women taking precedence over the physical ordeal of excision. But one might contend that the so-called coherent systems are in fact already undermined by what Mieke Bal has called a "countercoherence," the coherence of dissymmetry, of unequal power relations based on and reinforced by the use of language as an instrument of control, as a weapon capable of ensuring powerlessness in the victims. ${ }^{18}$

Consider, for example, that in many parts of Islamic Africa, notably the Sudan and Somalia, the worst form of insult is to call someone "a gaping vulva." There, speech acts perform tradition, reinforcing the

Circumcision in Ngugi's The River Between," in Ngambika: Studies of Woman in African Literature, ed. Carole Boyce Davies and Anne Adams Graves (Trenton, N.J.: Africa World Press, 1986), 208.

${ }^{17}$ Quoted in Koso-Thomas, Circumcision of Women, appendix 5, 106; emphasis added.

${ }^{18}$ Mieke Bal, Death and Dissymmetry: The Politics of Coherence in the Book of Judges (Chicago: University of Chicago Press, 1988), 18, 23, 138. 
doxa, the meaning of age-old practices. Ideologemes contribute to ensure powerlessness before the social system so that women may take their rightful place as subjected objects of desire. Women are named and defined by men who thus shape their self-understanding. Female self-knowledge is mediated by social perceptions conditioned by patriarchal culture.

Saadawi gives us an intimate and shocking look at this predicament in Woman at Point Zero. The protagonist Firdaus, whose name means "paradise" in Arabic, is taught the alphabet by her sexually abusive uncle (15). Later on, when she is living the life of a prostitute, the men to whom she submits also name and define her. They call her "slut," "bitch" (50), "you street walker... you prostitute" (49, 62), "you are not respectable" (70), and she begins to use those words herself (50), having internalized the vision conveyed by those speech acts which help perpetuate the status quo. For Saadawi, the construction of female subjectivity is clearly a process of gradual internalization of social knowledge-an internalization that engenders a split, a Spaltung, such as the one analyzed by psychoanalytic critics. For Saadawi, too, the female subject is a site of conflicts between an imposed social identity and a shared feminine identification mediated by the intimate experience of physical and verbal abuse, excision, and insult.

If, as Elizabeth Abel has argued, "it is too early for feminism to foreclose on psychoanalysis," then Saadawi provides us with a powerful example of the uses to which psychoanalysis can be put when we are attempting to understand, interpret, and resist certain debilitating cultural practices. As Abel puts it: "The urgency of theorizing subjectivity within a range of social contexts has made it less productive to reiterate old oppositions within psychoanalytic feminism, or between psychoanalysis and contemporary feminism, than to imagine more fluid intersections." ${ }^{\prime 19}$ Indeed, Saadawi's work as a psychiatrist and a novelist highlights the productive ways in which psychoanalysis, when it is not insulated from social and discursive practices, can help us make sense of, and indeed resist, those discourses that perpetuate women's oppression.

Thus, Firdaus realizes that words have a substance that is "palpable," "tangible" $(70,71)$, a materiality and a weight as real as that of the bodies that arouse and abuse her. As Firdaus's powerful anger makes clear, words can be means of control, abuse, and torture: "The words continued to echo in my ears... buried themselves in my head like some palpable material object, like $a$ body as sharp as the edge of a knife

${ }^{19}$ Abel, “Race, Class, Psychoanalysis?" 199, 186. 
which had cut its way through my ears, and the bones of my head to the brain inside... I could almost see them as they traversed the space separating his lips from my ears, like tangible things with a well-defined surface, exactly like blobs of spit, as though he had aimed them at me from between his lips" (70-71; emphasis added). These words are sharp and cutting, instruments of contempt and disdain, ejaculations ("blobs of spit") that defile and contaminate the hearer, as in an act of rape. Words maintain the dissymmetry of power between the sexes by entering the woman's consciousness, serving as scalpel in a metaphoric lobotomy that mirrors the genital excision: "The knife ... had cut its way through my ears ... to the brain inside." The soft tissue of the ear with its orifice that leads to the brain has an unmistakable sexual connotation. Words rape as surely as the penis, or the knife that the groom must use on his wedding night to open his bride's vulva and consummate the marriage. Saadawi thus conflates the act of speech and the act of sex in a way that clarifies and buttresses Bal's claims about dissymmetry.

Furthermore, words-uttered or written-have the same power as money: they are akin to paper money ("a mere piece of paper" [66], "the whole ten pound note" [65], contact with which produces in Firdaus a physical sensation as violent and as sudden as the unexpected orgasms provoked by her abusive uncle and clients. The symbolic value of words and money is thus conflated in a way that underscores their respective worth as currency, as means of exchange within a system that attributes to women a similar exchange value depending on their physical conformity to patriarchal standards of sexual beauty and purity. These standards are themselves based on a distortion of the idea of cultural symmetry which is presumed to exist between male and female processes of acculturation of the body.

Indeed, the question of symmetry is so often raised by traditionalists (see Wandja, for example) who want to emphasize either the equivalence between circumcision and excision or the need to leave cultural interpretations of Africa to Africans (or both) that we must examine its tenets. I have already mentioned that the dissymmetry "educated" versus "illiterate" is evoked whenever feminist points of view are brought into focus, especially because feminism is considered to be a foreignthat is, Western-import. ${ }^{20}$ The fact is that there is an obvious analogy between circumcision and excision: they both consist in the ablation of a part of the body for the ostensible purposes of hygiene and sexual attractiveness, and as a means of correcting the primal androgyny, or original bisexuality, of each being, a belief held by some Nilotic peoples

\footnotetext{
${ }^{20}$ See the critique of Thiam in Patterson, "Les mutilations sexuelles," 165.
} 
and by the Mande and Kwa of Western Africa. ${ }^{21}$ Hence for both sexes the operation is meant to inscribe a particular sexual identity on the body, to mark it as cultural, to give it symbolic meaning, that is, to differentiate it. In Foucault's terminology excision is part of a network of practices that "discipline" the body, functioning as a means of social control, and reproducing unequal relations of power along with gender identity. Mary Douglas has shown that there are symbolic relationships between the human body and the social body, that rituals can be interpreted in terms that link purity with order and impurity with disorder, the latter being a sign of danger and power. ${ }^{22}$ Excision, like circumcision, thus "purifies" the body, renders it fit to belong to its assigned place within a social order which it no longer threatens by its impure, abject nature-that is, its undifferentiated, dangerous sexuality. The painful ordeal to which the individual is subjected becomes a sign that the body can transcend pain, can endure. It is proof that the flesh is under the control of the spirit, in other words, that the embodied self can become sufficiently detached from its physical sensations to attain the state of "pure" and heroic subjectivity.

But there ends the expected symmetry. It becomes a dissymmetry when the focus is once again placed on the body. From a strictly anatomical perspective, only a piece of flesh is removed from the male member, whereas in the case of the female, a sexual organ is cut off. By all accounts the infliction of pain through circumcision cannot even begin to be compared with that of excision and infibulation. In The Hidden Face of Eve, Saadawi graphically describes her own experience of the knife, making a confession that can be juxtaposed to the silent testimonial of Firdaus in Woman at Point Zero:

I was six years old that night when I lay in my bed, warm and peaceful in that pleasurable state which lies half way between wakefulness and sleep, with the rosy dreams of childhood flitting by, like gentle fairies in quick succession. I felt something move under the blankets, something like a huge hand, cold and rough, fumbling over my body, as though looking for something. Almost simultaneously another hand, as cold and as rough and as big as the first one, was clapped over my mouth, to prevent me from screaming.

They carried me to the bathroom. I do not know how many of them there were, nor do I remember their faces, or whether they were men or women.

${ }^{21}$ Ehrlich, Femme blessée, 210-18.

${ }^{22}$ Michel Foucault, Discipline and Punish (New York: Vintage, 1979); Mary Douglas, Natural Symbols (New York: Pantheon, 1982) and Purity and Danger (London: Routledge \& Kegan Paul, 1966). 
The world to me seemed enveloped in a dark fog which prevented me from seeing. ... All I remember is that I was frightened and that there were many of them, and that something like an iron grasp caught hold of my hand and my arms and my thighs, so that I became unable to resist or even to move. I also remember the icy touch of the bathroom tiles under my naked body, and unknown voices and humming sounds interrupted now and again by a rasping metallic sound which reminded me of the butcher when he used to sharpen his knife before slaughtering a sheep for the Eid.

My blood was frozen in my veins... .

I imagined the thing that was making the rasping sound coming closer and closer to me. Somehow it was not approaching my neck as I had expected but another part of my body. Somewhere below my belly, as though seeking something buried between my thighs. At that very moment I realized that my thighs had been pulled wide apart, and that each of my lower limbs was being held as far away from the other as possible, gripped by steel fingers that never relinquished their pressure.... Then suddenly the sharp metallic edge seemed to drop between my thighs and there cut off a piece of flesh from my body.

I screamed with pain despite the tight hand held over my mouth, for the pain was not just a pain, it was like a searing flame that went through my whole body. After a few moments, I saw a red pool of blood around my hips....

I did not know what they had cut off from my body.... I just wept, and called out to my mother for help. But the worst shock of all was when I looked around and found her standing by my side. Yes it was her, I could not be mistaken, in flesh and blood, right in the midst of these strangers, talking to them and smiling at them, as though they had not participated in slaughtering her daughter just a few moments ago. (7-8; emphasis added)

If we follow Elaine Scarry in her argument that the pain of torture is a process that "unmakes" the world and the self, dissolving the boundary between inside and outside, conflating in an almost obscene way private and public, then the experience described by Saadawi underscores the "unmaking" of the child's environment. ${ }^{23}$ Visual and auditory perceptions become blurred; trust is forever destroyed as the mother's smiling face denies the reality of the shock and the pain. The strangers are described as body parts: a huge hand, cold and rough, an iron grasp, unknown voices, steel fingers. The child's own body reacts to the cold bathroom floor, to the rasping sound of metal being sharpened, to the metallic edge of the knife, and to the searing flame of pain that envelops her.

\footnotetext{
${ }^{23}$ Elaine Scarry, The Body in Pain: The Making and Unmaking of the World (New York: Oxford University Press, 1985), 53.
} 
But the disjunction and depersonalization caused by the pain is replaced by a strong sense of urgency and agency when she sees her sister being carried away in order to submit to the same fate. A mirroring effect comes into play when the sister's eyes meet and they are both united by the memory of a past and future pain: "They carried me to my bed. I saw them catch hold of my sister, who was two years younger, in exactly the same way they had caught hold of me a few minutes earlier. I cried out with all my might. No! No! I could see my sister's face held between the big rough hands. It had a deathly pallor and her wide black eyes met mine for a split second, a glance of dark terror which I can never forget" (8; emphasis added). The remarkable anger voiced by the six-year-old child who protests on behalf of her younger sister is an almost mythical example of the agency and autonomy manifested by the body despite its disintegrative suffering. Here symmetry exists powerfully: the excised child sees herself in her sister, and feels with the sister. The empathy is complete and total. Yet, in her novel Woman at Point Zero, it is precisely this question of empathy that will haunt the adult narrator who first resists identification with Firdaus as she struggles to understand her position vis-à-vis this "other" whose lower-class status and identity as a murderer, she initially feels, invalidates any comparison between them as symmetrical female subjects.

Woman at Point Zero is a lyrical testimonial that exemplifies the countercoherence of dissymmetry, the possibility of resistance to hegemonic pressures and to the cultural master narrative. Here the countercoherence of "the body in pain" manifests itself in a feeling of irretrievable loss which opposes sensations to language and ideology, subjective structures to cultural doxa. It is emblematic of issues raised by the work of Gayatri C. Spivak: the name of "the other woman," and the relationship between autobiography and "truth." In an interview with Sneja Gunew, Spivak has pointed out that "if one looks at the history of post-Enlightenment theory, the major problem has been the problem of autobiography: how subjective structures can, in fact, give objective truth." 24

These issues continue to be widely debated in recent feminist theory. Saadawi's work can be used as an excellent example of the self-reflexive questioning that can make feminist criticism sensitive to the way scholarly discourse names "the other woman" and appropriates her voice, for Woman at Point Zero is itself the appropriation of another woman's story by a scholar whose research on female offenders brings her into

\footnotetext{
${ }^{24}$ See Mary Lynn Broe and Angela Ingram, eds., Women's Writing in Exile (Chapel Hill: University of North Carolina Press, 1989), 420.
} 
close contact with the painful experiences of an extraordinary woman. This association between the educated researcher and the "(un)common criminal" changes the terms of the equation between "self" and "other" or "subjective" and "objective," enacting a transfer of values and feelings, locating the practice of writing at the intersection of multiple forms of knowledge.

Now, my own purpose here is also to make a scholarly appropriation: to scrutinize Saadawi's text, to examine the way in which it contrasts and collapses the language of patriarchy and the language of the body, bringing into focus those aspects of the narrative that might allow for its redefinition as self-portrait. By appropriating Firdaus's voice yet allowing intersubjective communication to occur, Saadawi raises the hope that it is in fact possible to come to an acceptable compromise regarding the possibility of interpretation and the role of "intervention" in the local practices of certain African societies. If autobiography is the means by which women represent themselves, then to understand their subjective experience of excision and its affective and cultural ramifications we need to look for traces of these preoccupations in their texts, and to listen to their silences.

Saadawi's work often has a hypnotic, incantatory quality which draws the reader into its world: if, as Spivak puts it, "subjective structures can, in fact, give objective truth," then Saadawi's struggle in Woman at Point Zero to come to terms with Firdaus, "the real woman" (1) whose story she tells, testifies to her efforts to elevate this case study to the status of an exemplary narrative of female oppression and emancipation-in other words, to give universal appeal to the story of this Cairo prostitute who is awaiting execution in Qanatir Prison for the murder of her pimp.

When, in her author's preface, Saadawi states: "Firdaus is the story of a woman driven by despair to the darkest of ends. This woman, despite her misery and despair, evoked in all those who, like me, witnessed the final moments of [her] life, a need to challenge and to overcome those forces that deprive human beings of their right to live, to love and to real freedom" (iv), she is emphasizing generally unproblematic values, but these values could hardly be taken for granted in Anwar Sadat's Egypt. What makes her story compelling, then, is the highly personal tone, the erosion of distance between the authorial self and the narrating " $\mathrm{I}$ " of Firdaus. Indeed, if Saadawi is first drawn to Firdaus because of her exceptional nature, the focus soon shifts to their shared experience of oppression as women in a patriarchal culture. What the text puts in motion is a strategy of displacement and identification between two women who are "objectively" very different- 
from the point of view of their respective social classes, their education and profession-but whose intimate experiences as women are uncannily similar. The narrative suggests that the universal can be known only through the particular or the personal, that it is the concrete subjective experience of this "other woman" that allows the scholar to relate to her as woman and sister, and to bring her back to life through her writing.

There is, finally, an ironic parallel. Six years after the publication of her book, on September 5, 1981, Saadawi herself became a political prisoner, along with a thousand other people alleged to have committed crimes against the state, and whom President Sadat considered to be threats to the stability of his regime. The telling of Firdaus's story thus becomes a rehearsal for Saadawi's own descent into the hell of an Egyptian prison. Saadawi is, and will become, Firdaus, the double that compels her. To tell Firdaus's story is to give voice to the "other" that haunts her, to see her own face in the contours of the prostitute's narrative, and to be provided with a moving link to her own experiences as an excised woman.

Trained as a research scientist, Saadawi initially tries to distance herself from Firdaus, struggling to remain faithful to the (male) scholarly principles of "objectivity" which she has learned to value in her profession. She tries to maintain her calm, her detachment as a scientist, while stressing the disturbing and depersonalizing impact of the emotions that take hold of her: "Subjective feelings such as those that had taken hold of me were not worthy of a researcher in science. I almost smiled at myself as I opened the door of my car. The touch of its surface helped to restore my identity, my self-esteem as a doctor" (5; emphasis added). The researcher in her exhibits a Western and male belief in the importance of autonomy and rationality. As Jessica Benjamin has argued: "Both in theory and practice [Western] culture knows only one form of individuality: the male stance of overdifferentiation, of splitting off and denying the tendencies toward sameness, merging, and reciprocal responsiveness." ${ }^{\prime 25}$ That is why Saadawi tries to negate the value of sensory perceptions in the acquisition of knowledge: when the prison warder tells her that she "senses" that Firdaus "knows" Saadawi, the author ponders, "Why should that indicate that Firdaus really knew me?" (5). Because Saadawi is powerfully attracted to Firdaus, she fears for her autonomy and objectivity. But her discovery of the "sameness"

${ }^{25}$ Jessica Benjamin, "The Bonds of Love: Rational Violence and Erotic Domination," in The Future of Difference, ed. Esther Eisenstein and Alice Jardine (New Brunswick: Rutgers University Press, 1985), 46. 
of their experiences militates against her continued adherence to male standards of rationality. Her self-doubts signal a move toward indifferentiation: Firdaus becomes a figure for the sister whose eyes succeeded in bringing Saadawi's disintegrative self/world back to a coherent point where agency-in the form of resistance to excision, as well as in the act of storytelling-became possible again because she identified and merged with the feelings of her sister.

Firdaus first refuses to see Saadawi, and this rejection threatens to undermine the doctor's self-confidence, her faith in her work: "Compared to her, I was nothing but a small insect crawling upon the land amidst millions of other insects" (3). But however much she may try to distance herself from Firdaus, Saadawi cannot escape the gradual but ineluctable fusion with her case study. The narrative sets this course in motion from the very beginning: both women experience feelings of self-doubt for which they compensate by expressing a need to "feel superior to everyone else" (11). Although Saadawi understands that Firdaus's refusals are directed not at her personally "but against the world and everybody in it" (5), she feels threatened by Firdaus's strength. When Firdaus finally agrees to talk, and the physician is called back, Saadawi lyrically describes her feelings of jubilation: "I walked with a rapid, effortless pace, as though my legs were no longer carrying my body. I was full of a wonderful feeling, proud, elated[,] happy. The sky was blue with a blueness I could capture in my eyes. I held the whole world in my hands; it was mine. It was a feeling I had known only once before, many years ago. I was on my way to meet the first man I loved" (6).

Saadawi's dependence on Firdaus's acceptance of her erodes all her attempts to keep her distance. A doubling occurs, and functions as a metonymic displacement between author and narrator whose voices echo each other, thus making it hard for the reader to know who speaks. Saadawi begins a journey which takes her into Firdaus's world, under Firdaus's control: when she enters the cell to talk, it is Firdaus who orders her to "sit down on the ground" (7), and who demands, "Let me speak. Do not interrupt me" (11). Saadawi loses her sense of reality, does not feel the cold and bare ground under her, becoming completely absorbed in "the voice of Firdaus" (7), as if entering a dream or a trancelike state of complete self-dissociation. The first and the last parts of the book, framing Firdaus's actual autobiographical tale, respectively end and begin with the same passages describing the author's entry into an oceanic state: "It was the cold of the sea in a dream. I swam through its waters. I was naked and knew not how to swim. But I neither felt its cold nor drowned in its waters" $(7,107)$. 
The novel thus begins and ends by blurring the distinctions between "subject" and "object," psychiatrist and case study, author and prisoner, biography and autobiography, fiction and documentary. The narrative seems to enact a pattern which, according to Rita Felski, is common to the genre of the feminine confession, and to its authors, namely, "their overwhelming yearning for intimacy." Felski asks: "What ... are the reasons for this blurring of the distinction between autobiography and fiction in feminist literature? Feminist confession exemplifies the intersection between the autobiographical imperative to communicate the truth of unique individuality, and the feminist concern with the representative and intersubjective elements of women's experience." She later remarks: "Feminist confession often reveals particularly clearly the contradictions between the desire for total intimacy and union, which seeks to erase all boundaries between desire and its object, and the act of writing as a continuing deferral of any such identity." ${ }^{26}$ In Woman at Point Zero, the desire for intimacy is first of all the author's. Saadawi develops a strong need to be close to Firdaus, to understand her and be accepted by her. The decision to write a novel is an attempt to deal with this interest and fascination which had developed during the interviews Saadawi carried out in the prison cell: "[Firdaus] vibrated within me, or sometimes lay quiet, until the day when I put her down in ink on paper, and gave her life after she had died" (iii).

"Until I put her down on paper": by writing down and giving back the other woman's life, Saadawi assumes control over the obsession that had consumed her. But Firdaus, too, yearns for intimacy. When she meets Sharifa Salah el Dine, the madam who becomes her mentor, or when she talks of her love for Ibrahim, a co-worker, it is in terms similar to those used by Saadawi: "The sky over our heads was as blue as the bluest sky" (51); and "It was as though I held the whole world captive in my hands. It seemed to grow bigger, to expand, and the sun shone brighter than ever before. Everything around me floated in a radiant light" (82). The repetitions form a leitmotif which interweaves Saadawi's subjectivity with Firdaus's. Both voices have merged into one, both bodies experience the same feelings of loss and detachment from surrounding reality with occasional and fleeting experiences of fulfillment. Past and present, self and other mirror each other, and the narrative accentuates the interchangeability of speaker and listener as intimate

\footnotetext{
${ }^{26}$ Rita Felski, Beyond Feminist Aesthetics: Feminist Literature and Social Change (Cambridge: Harvard University Press, 1989), 109, 93, 108.
} 
and private experiences point to a common sense of loss and betrayal deeply rooted in their memory.

Since the preface and the first and last parts of the narrative relate the author's personal reactions to Firdaus and situate the middle part as a retelling, in the first person, of Firdaus's oral confession, to read the novel is to be twice removed from the original story, which is, however, retold in a way that preserves the flavor of the oral exchange. The almost obsessive use of repetition as a narrative device allows the reader to enter into the consciousness of both subjects, to take part in an organic process of storytelling, in which it becomes impossible to separate the teller from the tale. ${ }^{27}$ Saadawi/Firdaus tells a story that unmasks an ancient truth about patriarchy, namely, that women need not fear what enslaves them, that freedom and "reciprocal responsiveness" is possible. Even if the outcome is death, the story is a posthumous lesson in courage-a lesson that Saadawi also gives us as an activist and a writer of "resistance literature" whose books are banned in her own country. ${ }^{28}$

As she explains in her introduction to The Hidden Face of Eve, Saadawi sees her writing as having a social function which is bound to disturb and unsettle those in power: "It was also natural that a small minority express their fear, or even panic, at words written by a pen sharp as a scalpel that cuts through tissue to expose the throbbing nerves and arteries embedded deep in a body.... My pen will continue to lay bare the facts, clarify the issues, and identify what I believe is the truth" (3; emphasis added). Saadawi uses her pen as a scalpel, turning back on society the instrument of torture that it used on her. Like her, Firdaus was marked at a very young age by the mutilation of excision, by the intervention of the mother and of her accomplice, the woman who carries "a small knife or maybe a razor blade" (13). Firdaus mentions this initial trauma without any commentary. It is a brief parenthesis, a secret no sooner shared than buried in the enveloping silence of the text. This act is never again mentioned. But what returns is the insistent questioning of the body, of its sensations of pleasure and pain, "a pleasure [she] ... had lived in another life ... or in another body that was not [her] body" (48). Identical terms are used seven times (14, 22, 26, 33, $48,56,78)$ in the narrative to describe these sensuous physical impressions. Firdaus's confession uses this refrain to underline the link be-

\footnotetext{
${ }^{27}$ As Trinh T. Minh-Ha has observed: "In this chain and continuum, I am but one link. The story is me, neither me nor mine.... My story, no doubt is me, but it is also, no doubt, older than me." Trinh T. Minh-Ha, Woman, Native, Other: Writing Postcoloniality and Feminism (Bloomington: Indiana University Press, 1989), 122-23.

${ }^{28}$ See Barbara Harlow, Resistance Literature (New York: Methuen, 1987), 137-40.
} 
tween her unfulfilled desire for intimacy and the erotic awakenings which set her body adrift toward innumerable male bodies, toward prostitution-passively at first, then freely chosen because "as a prostitute [she] had been looked upon with more respect" (75) than when she was a "respectable" (70) employee.

Firdaus's silence is in sharp contrast to Saadawi's graphic confession (cited earlier) which fills in the blanks of the novel. In both cases the mother is cast as an instrument of the patriarchy, as the means by which "femininity" is initially reproduced, thus allowing the system to perpetuate its hold on each generation of girls. For Firdaus, the betrayal of the mother and the loss of intimacy is metaphorized throughout in the use of a recurring trope: it is the image of two eyes, "two rings of intense white around two circles of intense black" (17), in which each color grows more intense, more engulfing. Firdaus is overcome by the gaze which is linked at first to her mother's enveloping, supportive presence: "Two eyes to which I clung with all my might. Two eyes that alone seemed to hold me up" (17). Later these eyes are evoked when she meets Iqbal, a schoolteacher, and the feeling is one of intense, nameless pleasure: "I held her eyes in mine, took her hand in mine. The feeling of our hands touching was strange, sudden. It was a feeling that made my body tremble with a deep distant pleasure, more distant than the age of my remembered life, deeper than the consciousness I had carried with me throughout" (29-30). This "deep distant pleasure" is articulated as a "memory," as the trace within the body of "something no sooner remembered than forgotten" (33), intangible yet real, a loss of physical being that motivates and subtends her later denunciations of the familial, social, and political structures that maintain sexual oppression.

It is particularly interesting that the pervasive and undefined sense of loss communicated by Firdaus should correspond so precisely to what object relation theorists have articulated as an archaic yearning for the mother's body, for the plenitude of indifferentiation. In her discussion of mother-infant relationships, Nancy Chodorow, for example, has argued that this early relationship, with its issues of "primary intimacy and merging" is crucial in establishing the foundation for future adult relationships. ${ }^{29}$ Adults all have some aspect of self that wants to recreate the experience of primary love, the feeling of comfort and satisfaction derived from the sense of identification with another. As Michael Balint has suggested, "This primary tendency ... is the final aim

${ }^{29}$ Nancy Chodorow, The Reproduction of Mothering: Psychoanalysis and the Sociology of Gender (Berkeley: University of California Press, 1978), 79. 
of all erotic striving." ${ }^{\prime 30}$ In Saadawi's narrative, the mother-daughter relationship is based on a fundamental lack-the lack of trust, the lack of physical continuity between the two-which contrasts sharply with the lateral, sisterly identification described at the scene of excision in The Hidden Face of Eve. This lack engenders a desire for nurturance which gets translated into an erotic longing for intimacy with Iqbal, Sharifa, or Ibrahim.

It must be noted that the death of Firdaus's mother is immediately followed by a move from the familial home and the native village to the city and her uncle's apartment, where she has her first glimpse of herself in a mirror: the scene is one of misrecognition which fills her "with a deep hatred for the mirror" (21), for the features of her face which remind her of either her father ("the big ugly rounded nose") or her mother ("this thin-lipped mouth" [20]). Fragmented by disconnections, her image of herself points to the inaugurating experience of the self-portraitist as described by Michel Beaujour: "emptiness and absence." ${ }^{\prime 31}$ Separation from her rural home breeds self-hatred and propels Firdaus on a search for other experiences of love and closeness which will reproduce the primary intimacy of early childhood, the experience of "boundary confusion or equation of self and other." ${ }^{32}$ Also worth noting is Saadawi's first encounter with Firdaus, an encounter that actually places Firdaus in an ambiguous position in relation to gender, thus suggesting that her sexual identity is androgynous, and therefore disruptive and disturbing to the social order.

Thus, when the prison doctor first describes her to the authornarrator, Saadawi reports his words in indirect speech: "[He] told me that this woman had been sentenced to death for killing a man. Yet she was not like the other female murderers held in prison" ( 1 ; emphasis added). It is through his words that the reader and the narrator first encounter Firdaus. He inscribes her as a feminine presence/absence, an enigmatic and silent figure ("She... won't speak to anyone... she asked for pen and paper... Perhaps she was not writing anything at all"), sensual and duplicitous ("If you look into her face, her eyes, you will never believe that so gentle a woman can commit murder" [1]). But, by contrast, what the narrator hears is a strong, highly masculine

\footnotetext{
${ }^{30}$ Quoted ibid. As Abel has noted, "Feminist object relations theory ... explicitly locates the production of gendered subjectivity in historically specific and socially variable caretaking arrangements" (185). It thus seems highly appropriate to use Chodorow to interpret Saadawi's novel.

${ }^{31}$ Michel Beaujour, Miroirs d'encre (Paris: Seuil, 1980), 9.

${ }^{32}$ Nancy Chodorow, "Family Structure and Feminine Personality," in Woman, Culture, and Society, ed. Michelle Z. Rosaldo and Louise Lamphere (Palo Alto: Stanford University Press, 1974), 57-58.
} 
voice: "The voice was hers, steady, cutting deep down inside, cold as a knife. Not the slightest wavering in its tone" (6). This voice connotes an instrument: the knife that foreshadows the murder of the pimp. The cold-blooded murder is the ultimate act of resistance and liberation on the part of Firdaus, an act comparable in fact to the act of writing for Saadawi, since writing produces similar consequences-imprisonment, solitary confinement-and since the description of the murder echoes Saadawi's metaphors for writing: "I raised the knife and buried it deep in his neck. ... I stuck the knife into almost every part of his body. I was astonished to find how easily my hand moved as I thrust the knife into his flesh, and pulled it out almost without effort. ... I realized that I had been afraid, and that the fear had been within me all the time, until the fleeting moment when I read fear in his eyes"(95).

To infer a parallel between the act of writing and the act of murder allows us to further the comparison and identification between Saadawi and Firdaus. There is dissymmetry between the act of writing, which is an act of creation, and the act of murder, which is a form of suppression; but there is also symmetry of the movements of the hand which moves the pen on the paper, or the knife into the flesh. To write (for a woman) and to kill are both forms of social transgression which lead to jail. The pen, which inserts words onto the page, and the knife, which indelibly marks the body, are means of control, tools whereby power can be appropriated. Since the foundational sign of appropriation and power is, of course, the masculine gesture of sexual possession, in which the penis can be used as a weapon, as in an act of rape, it becomes clear why Firdaus is such a subversive figure. Her fundamental transgression is that she reverses the traditional social roles on a symbolic as well as a real level: she trespasses on male sexual territory by using the knife as a means of penetration. Similarly, Saadawi's inscription of a woman's text on the masculine fabric of Egyptian culture is a form of trespass which deserves punishment because it interferes with the culturally acceptable codes of femininity.

What motivates Saadawi's writing is her hope for the future, her desire to "lay bare the facts." Similarly, when Firdaus talks about exchanging secrets and sharing stories with her school friend Wafeya, it is in order to paint a picture of the future which can give them both hope and courage: "If I had something to say, therefore, it could only concern the future. For the future was still mine to paint in the colours I desired. Still mine to decide about freely, and change as I saw fit.... Sometimes I imagined that I would become a doctor, or an engineer. ... I kept imagining myself as a great leader or head of state" (25). To appropriate the knife or pen is to appropriate the future: to dream of 
its possible configurations beyond the limitations of gender and class, and most of all beyond the limitations of mutilation. Saadawi's desire for an "objective" stance parallels Firdaus's wish for a "masculine" role. But each woman needs an interlocutor to legitimate her quest, to provide reciprocity and intersubjective exchange. This reveals each woman's preoccupation with issues central to the relational nature of female subjectivity, to what Chodorow calls "the lost feeling of oneness." ${ }^{\prime 33}$ Firdaus moves through the text with a physical yearning for the "paradise" of childhood, which is associated here with a time "before" - that is, before the betrayal by the mother and the torture of excision.

In contrast to her feelings of having a body which she does not experience as her own, her description of male bodies gives them a materiality and a specificity which borders on caricature. There is the ostentatious piety of the village fathers as they come out of the mosque every Friday, "nodding their heads, or rubbing their hands one against the other, or coughing, or clearing their throats with a rasping noise, or constantly scratching under the armpits and between the thighs" (13). The image of the father who eats alone in front of his starving children has echoes of Ousmane Sembene's depiction of the polygamous husband in his movie Mandabi: "His mouth was like that of a camel, with a big opening and wide jaws.... His tongue kept rolling round and round in his mouth as though it also was chewing, darting out every now and then to lick off some particle of food that had stuck to his lips, or dropped on his chin" (19). Her old husband has a disgusting face with an open and smelly sore; her clients, whether clean or dirty, rich or poor, are nothing but heavy bodies under which she closes her eyes and waits.

Physically and verbally battered, Firdaus feels a rage which culminates in the scene of the murder. It is a cathartic moment which helps her realize that anger sets her free to reappropriate language, to face "the savage, primitive truths" (102) and to be beyond fear and death. Firdaus finally names herself: she refuses to be a victim, and is willing to be a criminal because she prefers, as she puts it, "to die for a crime I have committed rather than to die for one of the crimes you have committed" (101). This you names the ultimate other, the one who creates my hell. ${ }^{34}$

${ }^{33}$ Chodorow, Reproduction of Mothering, 79.

${ }^{34}$ I allude here to Jean-Paul Sartre's famous remark, "L'enfer, c'est les autres," in his play Huis clos (No Exit). 
To the question Spivak asks-"How am I naming [the other woman]? How does she name me?"-Saadawi might answer in the words of Roland Barthes and Nadine Gordimer: that a "writer's enterprise-his [sic] work-is his [sic] essential gesture as a social being," and that writers "take risks they themselves do not know if they would." ${ }^{35}$ When Saadawi braids her identity with that of Firdaus because of their shared experience of pain and betrayal, she gives us a powerful example of feminine textuality as what I call métissagé, as dialogical hybrid which fuses together heterogeneous elements. ${ }^{36}$ Because Saadawi's use of the pen lands her in jail just as surely as Firdaus's use of her knife, we are in the presence of a mutual and reciprocal "naming" which effaces differences in order to point to an essential truth: that beyond their social differences, the two women share a nominal essence qua excised women. ${ }^{37}$ Since this sexual mutilation is the most important cultural signifier of femininity, "biological" femininity becomes a culturally determined fact, linked to specific local practices. When Saadawi denounces those practices, she puts herself in jeopardy. By appealing to universal human rights, she attempts to build bridges across cultures, showing the validity of a "Western" mode of analysis (psychoanalytic object relations theory) which allows her to name her subjective experience of pain and to situate it within an intersubjective context. As a critic who does not belong to the Islamic Egyptian culture, I am nonetheless interpellated by this dimension of the narrative, and I must respond to it in a way that "universalizes" the integrity of the body. But, I would argue, this form of universalism does not objectify the other and subsume her into my worldview: what it does is create a relational space where intersubjectivity and reciprocity become possible.

${ }^{35}$ Nadine Gordimer, The Essential Gesture: Writing, Politics, and Places (New York: Knopf, 1988), 286-87. She is using Roland Barthes's formulation in Writing Degree Zero, in Barthes, Selected Writings, ed. and intro. Susan Sontag (London: Fontana, 1983), 31.

${ }^{36}$ See Françoise Lionnet, Autobiographical Voices: Race, Gender, Self-Portraiture (Ithaca: Cornell University Press, 1989), chap 1.

${ }^{37}$ See Diana Fuss, "Reading Like a Feminist," Differences 1.2 (Summer 1989): 78, and Essentially Speaking: Feminism, Nature, and Difference (New York: Routledge, Chapman \& Hall, 1989). 